\title{
URBAN FORESTS AND PARKS AS PRIVACY REFUGES
}

\author{
by William E. Hammitt
}

\begin{abstract}
U rban forests and parks are forested areas that can serve as refuges for privacy. This article presents a conceptual argument for urban forests and parks as privacy refuges, and data that support the argument. $0 n$-site visitors $(n=610)$ to four Cleveland, O hio, U .S., M etroparks were surveyed in 1995. R esults indicated that considerable amounts of privacy were obtained during visits to the urban forests and parks, that people spent an average of two-plus hours per visit to these privacy refuges, that certain settings (habitats) within the refuges were preferred over others for privacy, and that "reflective thought" was the most important function (benefit) that privacy served within the refuges. The findings have implications for preserving and managing urban forests and parks as nearby refuges where the basic human need for privacy can be found.
\end{abstract} estry.

Key Words. Benefits; solitude; visitor surveys; urban for-

U rban forests and parks, though near homes, offer removed settings and/ or refuges from everyday home and work environments where people can get away and enjoy the psychological and recreational benefits of privacy. Privacy in most environments is known to be a basic psychological need of humans (Altman 1975; Proshansky et al. 1976). It has also been documented to be an important factor for people visiting forests and parks and has been shown to serve many beneficial functions during visits to these forested areas (Stankey 1973, 1989; H ammitt and Brown 1984; $\mathrm{H}$ ammitt and $\mathrm{R}$ utlin 1995).

Forested environments and privacy are somewhat synonymous, for forest environments are commonly thought of as natural areas where one can get away and find an element of privacy. In this sense, they serve as refuges from the nonprivacy domains of home and work environments (Westin 1967; A ppleton 1975; $\mathrm{H}$ ammitt 2000). This is not to say that elements of privacy cannot be found at home (e.g., the basement hideaway) or at work (e.g., the laboratory). However, forests, parks, and associated natural areas tend to serve as macro-environments where privacy is more extensive compared to settings within home and work places (Kaplan and Kaplan 1989).

The purpose of this article is to present a conceptual basis for urban forests as privacy refuges, to document use patterns and the importance of urban forests and parks as privacy refuges, and to examine some of the preferred habitats and functions of privacy within these refuges.

\section{HUMAN NEEDS FOR PRIVACY}

Considerable research has been conducted on privacy (Altman 1975; Proshansky et al. 1976; Klopfer and R ubenstein 1977; Hammitt 1982; $\mathrm{H}$ ammitt and Brown 1984; H ammitt and R utlin 1995; N ewell 1995; Pederson 1997, 1999). H owever, privacy remains a vital basic need of humans and can be found in most environments, yet its benefits still are not yet fully understood (Klopfer and $R$ ubenstein 1977). Privacy is a means by which people adjust information-processing mechanisms to the barrage of personal and social stimuli that they encounter in daily life. It serves as a mechanism for controlling the environmental situation in which one must function. In this sense, privacy is not a permanent state of being, but a voluntary and temporary withdrawal of a person from general society through physical or psychological means, either in a state of solitude or small-group intimacy or, when among larger groups, in a condition of anonymity or reserve (Westin 1967). In addition to these four states of privacy, Westin argues that privacy serves four basic functions. Personal autonomy is the need to avoid being manipulated or dominated wholly by others; to safeguard one's sacred individuality. Emotional release provides for respite from the psychological tensions and stresses of social roles in everyday society. Self-evaluation is the need to integrate one's experiences into a meaningful pattern and to exert individuality on events. Limited and protected communication consists of two aspects: (1) providing opportunities needed for sharing confidences and intimacies with those trusted, and (2) setting necessary boundaries of mental distance in interpersonal situations.

The word "desired" is important when studying privacy, for undesired privacy can occur (i.e., isolation) and be an unwanted environmental, psychological, and even recreational state. H owever, because urban forest experiences are usually self-selected and associated with elements of freedom, they are presumed to offer opportunities for desired privacy rather than undesired privacy. 


\section{URBAN FORESTS AS REFUGES}

U rban forests and parks fulfill the requirements of refuge from many perspectives A basic Webster (1974) definition of refuge includes "shelter or protection from danger, trouble, etc.; anything to which one has resources for aid, relief, or escape." U rban forests and parks certainly are places that serve as a resource for relief and escape from home or work troubles and tensions, and aid in our daily lives.

$U$ rban forests and parks also fulfill the refuge requirement of being restorative environments where one can recover from urban-associated mental fatigue (Kaplan and Kaplan 1989). "Being away" is one of the major components of restorative environments, where one can "be away to" refuges, free from everyday places, routines, and tasks. Being away refers to temporary visits to preferred environments rather than escape from negative environments. Suburbanites, when visiting urban forests, often are not escaping a nonpreferred place but rather are seeking an opportunity to be away to a more preferred place that is natural, free from everyday tasks and routines, and offers elements for mental restoration. A s K aplan and Kaplan state, being away is grounded in the idea that "where one is headed may be as important as where one is coming from" (1989: 117). Being away, privacy, refuge, and restorative environment are all terms associated with urban forested places. U rban forests and/ or treed landscapes have been documented to be preferred landscapes for being away and restorative experiences (H ammitt 2000; Kuo et al. 1998).

A third perspective where urban forests and parks qualify as refuges is grounded in Appleton's (1975) treatment of the Prospect-R efuge Theory of landscape experiences. Prospect- $R$ efuge Theory postulates that the ability to see (prospect) without being seen (refuge) is a basic human need when in natural environments, and that it is a source of aesthetic satisfaction and preference during landscape experiences. U rban forests and parks, with their elaborate trail systems and edge environments, offer many opportunities for prospect and refuge ( $R$ uddell and $\mathrm{H}$ ammitt 1987). While Prospect- $\mathrm{R}$ efuge Theory is grounded in habitat theory, it is recognized as having symbolic meaning for humans in today's society. U rban forests and parks are symbolic refuges in the sense that they offer places where one can find degrees of privacy and thus not always be seen (as in everyday places, in everyday routines, and social roles). If symbolic refuges are places where one can find shelter (privacy) from always being seen (social roles), then forests can fulfill this requirement.

\section{METHODS}

\section{Study Area and Sampling Procedure}

The study was conducted at four urban forest/parks of the Cleveland $M$ etroparks in Cleveland, $O$ hio, U.S. In A ugust 1995, 689 visitors were contacted at the parks and asked to participate in a one-half page intercept survey at that time, to be followed later by a longer mail questionnaire. A total of 610 of the intercepted visitors agreed to participate by providing their name and address so that the mail-back questionnaire could be sent to them. $0 \mathrm{n}$ site sampling occurred over a 3-week period, including weekdays and weekends. A quota of 30 individuals was sampled per day.

The framework for sampling on-site respondents can best be classified as a stratified, nonproportional, convenience sample. The sample was stratified by park location and time of day. Three of the four parks were selected for sampling each day, with a 3-hour interval spent at each. The time intervals were morning (8:00 to 11:00 A.M.), afternoon (12:00 noon to 3:00 P.M.) and evening (5:00 to 8:00 P.M.). Due to the spatial location of the parks and traffic congestion, no random effort was made in selecting the specific parks and time intervals to sample each day. Instead, sampling locations and times were equally distributed among the parks by simply alternating park location and time of sample so that at least two of the three parks sampled each day were located on the same geographical side of Cleveland (e.g., east and west sides). At a given park during a given time interval, a trained researcher intercepted on-site visitors at major-use locations and while roving less-used areas.

\section{Mail Questionnaire Sample}

Shortly after completing the intercept survey cards, all individuals were mailed a questionnaire packet. Included in this packet were an eight-page questionnaire, cover letter, and a postage-paid return envelope. These packets were followed with an initial postcard reminder in about 10 days. W ithin another 10 to 14 days, a second wave of questionnaire packets was mailed to the remaining nonrespondents. Finally, a second postcard reminder was sent. The mailing procedure roughly corresponded to methods devised by Dillman (1978). O f the 610 individuals mailed a questionnaire, 422 returned usable questionnaires, for a final return rate of $69 \%$.

\section{The Survey Instruments}

The one-half page, on-site intercept card consisted of five questions and name and address information. The five 
questions dealt with use frequency of $M$ etroparks per month, length of stay, and importance of "being away from" and "being away to" motives for visiting the parks.

The eight-page mail questionnaire contained questions that were arranged into six information sections. For the purposes of this paper, the following content areas are of importance.

1. Travel distance and use patterns for the forest/ park refuges.

2. Privacy A chieved: R espondents were asked to indicate the amount of desired privacy they achieved from their park visit $(1=$ did not achieve my desired level of privacy, 10 = fully achieved my desired level of privacy). As a comparison, respondents were also asked the typical amount of privacy they normally achieve at the work and home environments (again on a 10-point scale).

3. B eing Away From and Being Away To: R espondents were asked to rate on a 10-point scale (ranging from $1=$ not important to $10=$ very important) how important the single-item reasons to be away from everyday places (i.e., home, work), and to be away to natural places (i.e., forests, parks) were on their visit to the M etropark. R espondents also were asked to rate the importance of 14 specific aspects of being away from (seven items) and being away to (seven items) opportunities for the park visit (using same 10-point rating scale as above). The 14-item measure was factor analyzed for underlying multi-item measures of the two being-away concepts.

4. R efuge-Setting Preferences for Privacy:Various (13) forest settings were rated on a 10-point scale $(1=$ do not prefer this setting for privacy to $10=$ prefer this setting for privacy) for experiencing privacy.

5. Functions of Privacy in R efuges:Twenty- seven individual functions that privacy might serve were rated on a 7-point scale ( 1 = extremely unimportant, 7 = extremely important) of importance.

\section{Data Analysis}

Factor analysis, involving principal components with varimax rotation, was used to determine common functions that privacy might serve in forest/ park refuges. Factor loadings had to be $\geq 0.40$ for items to be included in a factor, and only factors with eigenvalues $\geq 1.0$ were extracted. Also, the internal consistency reliability (C ronbach's alpha) of factors had to be $\geq 0.70$ for them to be retained. The remainder of the data were analyzed using standard descriptive statistics with t-tests used to test for mean differences.

\section{RESULTS AND DISCUSSION}

\section{Travel and Use of Urban Privacy Refuges}

$\mathrm{N}$ early $83 \%$ of visitors traveled to the refuges from home, while another $13.3 \%$ came from workplaces. The major means of travel were personal car $(94.8 \%)$ and walking (4.0\%). Average travel distance was 8.1 miles (SD $=18.2$ ), with 5 miles the most frequently reported distance. Travel time to the refuges averaged 16 minutes (SD $=9.2$ ).

0 nce at the refuges, visitors stayed an average of 2 hours and 12 minutes during a visit. T here was considerable variation in the length of park visits ( $S D=1.4$ hours), ranging from a minimum stay of 20 minutes to a maximum of 9 hours. The major activities at the refuges during this time were walking (34.1\%), picnicking (10.2\%), biking (7.6\%), jogging/running (7.1\%), and beach swimming (6.9\%). The most popular areas within the refuges for these activities were paved, all-purpose trails (62.6\%), unpaved trails through woods and meadows (32.9\%), and picnic areas (27.0\%). $\mathrm{N}$ early two-thirds (67.2\%) of refuge visitors used the areas alone or with only one other person.

\section{Privacy Received at Urban Refuges}

As stated in the literature review, privacy can be found in many types of environments. H owever, a case was made in the literature review that urban forests and parks may serve well the many requirements of a privacy refuge. To determine the utility of urban forests and parks as refuges to achieve privacy, visitors were asked to indicate the degree of desired privacy achieved while visiting the urban forest/ park environments. The degree of desired privacy typically achieved at everyday work and home environments was also obtained, as a baseline measure.

The degree of desired privacy achieved from the urban forests and parks was high, averaging $8.12(S D=2.02)$ on a 10 - point rating scale $(1=$ low level of privacy to $10=$ high level of privacy achieved). As a comparison, little privacy was typically achieved at work ( $x=3.55, S D=2.50$ ) and only a moderate amount occurred at home $(x=6.89, S D=2.55)$. These three degrees of desired privacy were significantly different at the $p=.001$ level. Thus, the data indicate that nearby urban forests and parks provide greater opportunities for achieving a higher degree of desired privacy than do work and/ or home environments, lending support for the claim that urban forests/ parks may serve as privacy refuges.

\section{Urban Privacy Refuges as Opportunities to Be Away}

W hile urban forests and parks may serve as nearby refuges where people can be away on a temporary basis and 
achieve a high degree of privacy, what do we know about the being-away properties of these privacy refuge experiences? The concept of a refuge, by definition, denotes a place "to which one has resources for aid, relief, or escape" (Barnhart 1960: 1018). Thus, both a positive (e.g., aid, relief) and negative (e.g., escape) aspect are associated with the concept of a refuge.

0 utdoor and urban recreation planners have commonly felt that a major reason for recreating in forested areas is escape- often defined as temporary escape from residential and more everyday environments. $R$ ecreation planners and researchers have also recognized that people visit forest and park refuges for the peace, tranquility, and restorative resources of these areas (Kaplan and Kaplan 1989). Thus, two major aspects - the desire to be away from the everyday place (e.g., home, work, etc.) and/ or to be away to a natural place- may both serve as properties of forest/park refuges.

To investigate the privacy and being-away properties of refuge visits in more detail, study respondents were asked to indicate the importance to them of "being away from" and "being away to" reasons for visiting the four M etroparks. They were also asked the importance of 14 specific aspects of being away from and to opportunities at the privacy refuges. When the two single item measures of being away were examined, vistors felt the opportunity to be away to a natural place was more important (based on a 10-point importance rating scale) than the opportunity to be away from the everyday place ( $x=8.50$ vs. 7.33 , $t(393)=8.52, p=.001$ ). Similar results were obtained for the 14-multiple-item measure, with being away to significantly $(p=.001)$ more important than being away from (Table 1). The opportunity to be away to "a place of peace and quiet" and "a forest environment" was quite important to visitors ( $x=8.65$ and 8.17 , respectively). Park environments and private places where there is not a set routine were next in importance. Least important were task-free environments ( $x=7.19$ ) and the opportunity to be away to less familiar settings $(x=5.80$ ).

Most of the being-away-from opportunities were rated as somew hat not important to moderately important (Table 1$)$. T he reasons to be away from family members ( $x=3.07)$ and everyday co-workers ( $x=4.67)$ were rated least important to visitors. Being away from specific work task(s), an overly familiar setting, and daily home routines were moderately important. Being away from daily work routines $(x=6.80)$ and crowded places $(x=7.06)$ were the most important to visitors. It would appear from this descriptive data that opportunities to be away to natural places, such as quiet forest and park envi- ronments that offer task- and routine-free private places, are more important to forest/ park visitors who responded to this survey than the opportunity to escape from crowded places, daily work and home routines, and associated people. However, both positive (attraction to) and negative (escape from) connotations are associated with urban forests and parks as privacy refuges.

Table 1. The importance of being away from everyday places and being away to natural places as rea sons for visiting forest/ park refuges.

\begin{tabular}{lll}
\hline & \multicolumn{2}{c}{ Importance } \\
\cline { 2 - 3 } Being-away situation & M ean & $\begin{array}{c}\text { Standard } \\
\text { deviation }\end{array}$ \\
\hline To be away from & & \\
crowded places & 7.06 & 2.96 \\
daily routines of work & 6.80 & 2.98 \\
daily routines of home & 6.20 & 2.84 \\
an overly familiar setting & 5.50 & 3.00 \\
specific work task(s) & 5.27 & 2.98 \\
everyday co-workers & 4.67 & 3.14 \\
family members & 3.07 & 2.74 \\
Grand meany & $\mathbf{5 . 5 4}$ & \\
To be away to & & \\
a place of peace and quiet & 8.65 & 1.87 \\
a forest environment & 8.17 & 2.12 \\
a park environment & 7.87 & 2.16 \\
a place where there is not a set routine & 7.39 & 2.74 \\
a private place & 7.27 & 2.63 \\
a task-free environment & 7.19 & 2.78 \\
a less familiar setting & 5.80 & 2.91 \\
Grand meany & $\mathbf{7 . 4 7}$ & \\
\hline
\end{tabular}

${ }^{2} \mathrm{M}$ eans based on a 10-point rating scale, where $1=$ not important and $10=$ very important.

y 7.47 vs. $5.54, t(342)=-20.64, p=.001$

\section{Privacy Preference Within Urban Forest/ Park Refuges}

There are many different settings within urban forest and park areas that might be preferred for finding and experiencing various degrees of privacy. Trail settings near water were the most preferred for privacy (Table 2). Forest trails along running water were highly preferred settings for privacy by nearly $75 \%$ of park visitors ( $x=8.10$ ). 0 ther trail environments, particularly through forested areas or natural areas, and trails that are unpaved were also preferred. Settings that visitors were more neutral toward for privacy included open trail and park fields, all-purpose trails, and picnic areas. Least preferred were open park fields ( $x=5.16)$ and all-purpose trails along roads ( $x=4.97$ ).

W hile forest and water settings tend to rate high for privacy, the elements of forest and water are not sufficient in and of themselves to guarantee privacy. For example, the 
settings of "waterfront areas with beach" and "forested areas with no obvious trails" while containing elements of forest and water, were rated in the neutral range of preference, and visitors showed the most variation in rating these two settings (SD $=3.04$ and 3.03, respectively). $N$ early as many people rated the two settings as not preferred as they did preferred. Privacy preference was quite diverse for forested areas with no obvious trails, where $16.1 \%$ rated it the lowest in preference while $12.3 \%$ rated it the very highest. Issues of safety and comfort, no doubt, are at play in the ratings of these types of forested areas for some visitors.

\section{Functions of Urban Forest Privacy}

If one accepts the argument that privacy is a basic psychological human need (Altman 1975), that considerable amounts of privacy can be obtained in urban forests and parks, that people spend an average of $2+$ hours per visit being away to these privacy refuges, and that certain settings (habitats) within the refuges are preferred over others for privacy, then an important question is "W hat are the functions that privacy is serving within these refuges?" Westin (1967) suggests four basic functions of privacy, which were defined earlier in this paper (e.g., personal autonomy, emotional release, selfevaluation, and limited protected communication).Twentyseven specific function items, based on Westin's four basic functions, were rated by refuge visitors as to how important each specific function of privacy is to them when visiting urban forests/ parks.

When the 27 items rated for privacy importance were analyzed for underlying functions in Cleveland, 0 hio, forest/ park environments, four functions or factors were derived. Twenty items met the factor analysis criteria for inclusion in the analysis and were grouped under four dimensions of privacy functions. reflective thought, distancing/ emotional release, creative thought, and intimate communication (Table 3). A discussion of these factors follows.

$R$ eflective thought was rated the most important ( $x=5.15$ on a 7-point scale) function that privacy served in the surveyed urban forest environments. U rban forests served Cleveland respondents by providing a relaxed period where past experiences can be reflected upon-where people can be alone with individual thoughts/feelings, can recover from troubled or depressing moments, for exploring/thinking through personal concerns, and regrouping thoughts. When "always on the go," it is difficult to reflect and integrate one's experiences into directed and meaningful patterns (Hammitt and Brown 1984). As pointed out by M idgley (1978), periods of integration are essential so that human behavior does not become diffused, disorganized, and counterproductive. Lacking periods of reflection and integration of one's thoughts and actions is both maladaptive and uncomfortable, and prohibits a state of cognitive clarity when contemplation and problem solving might occur (Kaplan 1978). People can seek natural environments and places (e.g., urban forests) to regain a desired state of cognitive clarity.

Closely associated with the function of reflective thought is a "relaxed period," where resting of the mind from society and mental fatigue and the release of psychological stress can occur. Being away from everyday routine, social roles, and accompanying stresses - to an environment that affords a relaxed period-is essential to clear the head so that the functions of regrouping, recovering, evaluating, and reflecting can proceed. Survey results indicate that urban forests are resources that aid this important function of privacy in our lives.

Distancing/ emotional release was rated the second most important function of privacy by survey respondents ( $x=4.95$ ). The function of disengaging from every day social roles where one can experience a period of time away from others' expectations is important as an emotional release from everyday life (Westin 1967). The individual item, "as an emotional release from everyday life" was rated the highest in importance of the original 27 privacy items 


\begin{tabular}{|c|c|c|c|c|}
\hline Dimension and factored items & $\begin{array}{l}\text { Factor } \\
\text { loading }\end{array}$ & $\begin{array}{l}\text { Item } \\
\text { mean }\end{array}$ & $\begin{array}{l}\text { Factor } \\
\text { mean }\end{array}$ & $\begin{array}{l}\text { Factor } \\
\text { alpha valuey }\end{array}$ \\
\hline Reflective Thought & & & 5.15 & .93 \\
\hline For being alone with one's individual thoughts and feelings & .7312 & 5.23 & & \\
\hline $\begin{array}{l}\text { For recovering from troubled or depressing moments in } \\
\text { one's life }\end{array}$ & .7252 & 5.01 & & \\
\hline $\begin{array}{l}\text { For exploring and thinking through personal matters and } \\
\text { concerns }\end{array}$ & .7087 & 5.16 & & \\
\hline For resting the mind from society and mental fatigue & .6989 & 5.52 & & \\
\hline As a relaxed period for reflecting upon past experiences & .6484 & 4.95 & & \\
\hline For regrouping one's thoughts & .6477 & 4.98 & & \\
\hline For releasing psychological stress & .6257 & 5.62 & & \\
\hline For maintaining a sense of individuality & .5805 & 4.75 & & \\
\hline Distancing/ Emotional R elease & & & 4.95 & .83 \\
\hline For disengaging from everyday social roles & .7851 & 4.95 & & \\
\hline $\begin{array}{l}\text { For experiencing a period of time aw ay from others' } \\
\text { expectations }\end{array}$ & .7104 & 4.92 & & \\
\hline As an emotional release from everyday life & .6488 & 5.67 & & \\
\hline $\begin{array}{l}\text { As an environment where one can maintain a desired } \\
\text { mental distance from other individuals }\end{array}$ & .5752 & 4.84 & & \\
\hline For limiting visual and verbal interaction with strangers & .5377 & 4.37 & & \\
\hline Creative Thought & & & 4.95 & .82 \\
\hline For the opportunity to explore new ideas & .6803 & 4.47 & & \\
\hline For a place to enjoy one's imagination & .6720 & 5.24 & & \\
\hline For being in an environment which inspires creative thought & .6701 & 5.08 & & \\
\hline For getting away to take a new and creative perspective & .6534 & 5.03 & & \\
\hline Intimate Communication & & & 4.51 & .88 \\
\hline $\begin{array}{l}\text { As an opportunity for sharing confidences and intimacies with } \\
\text { those one trusts }\end{array}$ & .8664 & 4.48 & & \\
\hline For talking over personal matters with intimate friends & .8412 & 4.51 & & \\
\hline As a private setting for communicating with a few friends & .7984 & 4.55 & & \\
\hline
\end{tabular}

${ }_{\mathrm{z}} \mathrm{M}$ ean values based on a 7 -point rating scale, where $1=$ extremely unimportant and $7=$ extremely important.

${ }^{Y}$ Cronbach's alpha.

$(x=5.67)$. Two other items related to limiting interactions with strangers and maintaining a desired mental distance from others were correlated with the functions of disengaging from social roles and emotional release in everyday environments. Although the emotional release function is somewhat similar to the reflective thought function, they remain distinct in that emotional release could occur without reflective thought. H owever, reflective thought cannot occur without emotional release. 0 ne must be able to release the "baggage" carried around in the head from the often emotionally filled everyday environment before reflective thought can occur (K aplan 1978).

Creative thought was equal in importance to distancing/ emotional release as a privacy function ( $x=4.95$ ). The function concerns an environment/ place that allows for considering unexplored new ideas, enjoying one's imagination, taking new and creative perspectives, and inspiring creative thought. This function is different from the reflective thought function in that it deals with new information rather than the integra tion and reflection of old or existing information. This is not to infer that reflective thought cannot lead to different ideas and does not involve new perspectives, but its major privacy function in this study seems to be related to the recovering, thinking through, and reflection upon past experiences

Intimate communication as a form of limited communication was the fourth and least important privacy function for respondents ( $x=4.51$ ). A private setting for communicating and talking over personal matters with intimate friends, and an opportunity for sharing confidences or intimacies with those trusted, is a function served by urban forests. The three items in this factor loaded the highest (had highest correlations) of any of the privacy scale items. 
People often have the need for disclosing and sharing intimate thoughts and feelings; however, most people are reluctant to go public with personal concerns or with items that are not well thought out. A friend before whom one can "think aloud," an individual whom one can trust with intimacies, is a valuable asset. Likewise, a private environmental setting and refuge that fosters disclosure of personal thoughts, and at the same time allows for the sharing of these ideas with selected individuals, can be an asset. U rban forests in Cleveland are one such environmental setting where this function might occur, considering that $67 \%$ of survey respondents visited the areas alone or with only one other individual.

\section{SUMMARY AND CONCLUSIONS}

Privacy and solitude have long been known to be major attributes and benefits of remote forest and wilderness environments (Hendee et al. 1990). H owever, less is known about the privacy aspects of close-to-home, forested areas in urban environments. This research, though one study, indicates that urban forests and parks also can serve as refuges where everyday privacy can be found. Specific findings from the $\mathrm{Cleveland}, \mathrm{O}$ hio study indicate that

- more privacy is achieved by survey respondents at urban forests and parks than at work and home environments.

- a high degree of privacy can be obtained during forest/park visits.

- visitors to the forests and parks in C leveland are attracted to these areas, rather than just escaping from less private places.

- heavily forested settings, when associated with nearby running water and/ or unpaved trails, are most preferred by respondents for finding privacy.

- privacy in forest/ park refuges serves several potential beneficial needs and psychological functions of human well being. Thus, there is preliminary data to support the concept of urban forests and parks as refuges of privacy.

H owever, a cautionary note is in order concerning the concept of refuge privacy. Privacy has self-determined (human) as well as setting-determined aspects. It is important to realize that the amount of privacy achieved depends on the desired forest/ use conditions and the ability of forest visitors to seek and create privacy states, in addition to preferred forest settings.

In conclusion, the findings of this study suggest some preliminary management implications for managing ur- ban forests as refuges for privacy benefits. For example, preferred and potential privacy settings would be expected to better serve the functions of privacy for individuals seeking privacy benefits. Identification of these preferred settings, their preservation and management, and manipulation through silvicultural, arboricultural, and recreation trail management, should serve to enhance the privacy refuge attributes of these areas. H owever, future research is needed before specific and definitive management prescriptions can be made. For example, future studies need to address the more specific questions and potential outcome implications of the following questions.

- Do visitors specifically seek particular places and settings within the urban forest context and achieve more desired privacy than while in less-specific places?

- Is it necessary to manage specific kinds of places and settings in the urban forest for supporting privacy or can places that are meant for other uses achieve equal levels of privacy?

- Is privacy achieved as a function of duration in specific settings or the nature of the setting itself?

- Does it matter whether one sets out to find privacy or happens upon it?

Perhaps the ultimate outcome from this line of research should be to verify just how large, or small, a beneficial role that privacy derived from urban forest recreation plays in society for some people, considering the prevalence and importance of privacy as a human psychological need (Altman 1975).

\section{LITERATURE CITED}

Altman, I. 1975. T he Environment and Social Behavior: Privacy, Personal Space, Territory, C rowding. Brooks/C ole, M onterrey, CA.

A ppleton, J. 1975. The Experience of Landscape. W iley, London, England.

Barnhart, C.L. (Ed.). 1960. The American College Dictionary. $\mathrm{R}$ andom $\mathrm{H}$ ouse, $\mathrm{N}$ ew York, $\mathrm{N}$ Y.

Dillman, D.A. 1978. M ail and Telephone Surveys: The Total D esign M ethod. John W iley and Sons, N ew York, N Y.

H ammitt, W.E. 1982. Cognitive dimensions of wilderness solitude. Environ. Behav. 14:478-493.

Hammitt, W.E. 2000. The relationship of being-away and privacy in urban forest recreation environments. Environ. Behav. 32:521-540.

$\mathrm{H}$ ammitt, W.E., and G. Brown. 1984. Functions of privacy in wilderness environments, Leisure Sci. 6:151-166. 
H ammitt,W.E., and W.M . R utlin. 1995. U se encounter standards and curves for achieved privacy in wilderness. Leisure Sci. 17:245-252.

H endee, J.C., G.H. Stankey, and R .C. Lucas. 1990. W ilderness $\mathrm{M}$ anagement. Fulcrum Publishing, Golden, $\mathrm{CO}$.

K aplan, S. 1978. Attention and fascination:T he search for cognitive clarity. In Kaplan, S., and R. Kaplan (Eds.). Humanscape: Environments for People. D uxbury Press, N . Scituate, M A.

Kaplan, R ., and S. Kaplan. 1989. The Experience of $\mathrm{N}$ ature: $\mathrm{A}$ Psychological Perspective. Cambridge U niversity Press, N ew York, NY.

K lopfer, P.H ., and D.E. R ubenstein. 1977.T he concept privacy and its biological basis. J. Soc. Iss. 33:52-65.

K uo, F.E., M. Bacaicoa, and W.C. Sullivan. 1998. Transforming inner city landscapes: Trees, sense of safety and preference. Environ. Behav. 30:28-59.

M idgley, M. 1978. Beast and M an: The R oots of Human $\mathrm{N}$ ature. C ornell U niversity Press, I thaca, N Y.

N ewell, P.B. 1995. Perspectives on privacy. J. Environ. Psychol. 15:87-104.

Pederson, D.M. 1997. Psychological functions of privacy. J. Environ. Psychol. 17:147-156.

Pederson, D.M. 1999. Model for types of privacy by privacy functions. J. Environ. Psychol. 19:397-405.

Proshansky, H.M ., W.H . Ittelson, and L.G. R ivlin. 1976. Freedom of choice and behavior in a physical setting. Environmental Psychology: People and Their Physical Settings. H olt, R inehart, and W inston, N ew York, N Y.

R uddell, E.J., and W.E. H ammitt. 1987. Prospect refuge theory: A psychological orientation for edge effect in recreation environments. J. Leisure R es. 19:249-260.

Stankey, G.H. 1973. Visitor perception of wilderness recreation carrying capacity. Intermountain Forest and $R$ ange Experiment Station, U SDA Forest Service, R es. R ep. IN T-142. 0 gden, UT.

Stankey, G.H. 1989. Solitude for the multitudes: M anaging recreational use in wilderness. Public Places and Spaces. Plenum Press, $\mathrm{N}$ ew York, $\mathrm{N}$ Y.

Webster. 1974. Webster's N ew World Dictionary. 2nd C ollege Edition, D.B. Guralnik (Ed.). W illiam Collins \& World Publishing C $0 .$, Inc., N ew York, N Y.

Westin, A.F. 1967. Privacy and Freedom. Atheneum, N ew York, N Y.

Acknowledgments. This research was funded through a cooperative agreement with the U SDA Forest Service N orth Central Forest Experiment Station, Chicago. Dr. John D wyer and the scientists at the Forestry Sciences Laboratory are thanked for their insights and support during the study. The Cleveland, O hio, M etropark System, particularly Dr. R obert Bixler, are acknowledged for providing the study site and for logistics during the field research. Dr. M ichael E. Patterson of the U niversity of M ontana was a co-investigator on the project during his tenure at $\mathrm{C}$ lemson $\mathrm{U}$ niversity.
Professor

$D$ epartments of F orest $R$ esources/ Parks, R ecreation and Tourism $M$ anagement

282A L ehotsky $\mathrm{H}$ all

C lemson U niversity

C lemson, SC, 29634-0735, U.S.

H ammitw@ clemson.edu

Résumé. Les forêts urbaines et les parcs sont des espaces forestiers qui peuvent servir de refuges pour l'intimité. C et article présente un argument conceptuel en regard des forêts urbaines et des parcs comme refuges pour l'intimité, ainsi que des données pour supporter cet argument. Des visiteurs $(n=610)$ dans quatre parcs métropolitains de Cleveland en $\mathrm{O}$ hio ont été suivis directement sur le terrain en 1995 . Les résultats ont indiqué qu'un degré considérable d'intimité a été obtenu lors des visites dans les forêts urbaines et les parcs, que les gens passaient en moyenne plus de deux heures par visite dans ces refuges d'intimité, que certains environnements (habitats) dans ces refuges étaient préférés à d'autres pour l'intimité, et que la notion de «milieu de réflexion » était la fonction (bénéfice) la plus importante que servait l'intimité au sein de ces refuges. $C$ es découvertes ont des implications sur les préservation et la gestion des forêts urbaines et des parcs comme refuges de proximité où le besoin fondamental des humains pour l'intimité peut être retrouvé.

Zusammenfassung. Stadtwälder und Parks sind bewaldete $R$ egionen, die als privates $R$ ückzugsgebiet dienen können. Dieser Artikel präsentiert konzeptionelle Argumente zur Befürwortung von W äldern und Parks als R ückzugsgebiet und liefert $D$ aten dafür. 1995 wurde in Cleveland, O hio die Besucherzahlen von 5 $M$ etroparks $(n=610)$. Die R esultate zeigten, dass während der Parkbesuche ein hoher Anteil an Privatsphäre genossen wurde, dass die Leute durchschnittlich 2 und mehr Stunden im Park verbringen, dass bestimmte Zonen mehr aufgesucht wurden als andere und dass ,Gedankenreflektion' ein $\mathrm{H}$ auptanliegen in diesen Zonen war. Die Ergebnisse sprechen für den Erhalt und $\mathrm{M}$ anagement von Stadtwäldern und Parks als $\mathrm{N}$ aherholungsgebiet, um hier ein Grundbedürfnis an R ückzug und R eflektion zu gewährleisten.

Resumen. Los parques y bosques urbanos son áreas forestadas que pueden servir como refugios para la privacidad. Este artículo presenta los datos que soportan el argumento conceptual de los parques y bosques urbanos como refugios de privacidad. Un estudio de visitantes $(n=610)$ para cuatro M etro parques de Cleveland (O hio) fue llevado a cabo en 1995. Los resultados indican que se obtuvo considerable cantidad de privacidad durante las visitas a estos parques, que la gente gasta en promedio más de dos horas por visita a estos refugios de privacidad, que ciertos hábitat dentro de los refugios fueron preferidos sobre otros, y que el "pensamiento reflexivo" fue la función más importante (beneficio) que la privacidad proporcionó dentro de los refugios. Estos hallazgos tienen implicaciones para la preservación y manejo de los bosques y parques urbanos como refugios donde se satisfacen las necesidades básicas humanas de privacidad. 